\title{
European Physical Society Application for Individual Ordinary Membership
}

please return this form to

EPS, BP 2136, F-68060 Mulhouse Cedex, France

1 Personal details please write in capital letters

Last Name

First name(s)

Date of birth

11

Nationality

Office phone +

Home phone +

$\mathrm{Fax}+$

Email

Full address

postcode

country

\section{Professional details}

Highest academic degree

Institution

Current position

Specialization

3 Type of membership Are you a member of one of the societies listed on the right? If you are a member of one of the national member societies, tick yes below and pass to question 4 . If you are a member of one of the collaborating societies listed on the right, tick yes below and pass to question 4. Otherwise, tick no and pass to section 5 .

Yes

$$
\text { No }
$$

4 Which society are you a member of? Please underline the national member society or the collaborating society on the left. There is no need to complete section 5 , pass to section 6 .

5 Please ask two Individual Ordinary Members of the European Physical Society to sign this form. Please print their names and addresses.

Signature

Signature

Name and address

Name and address

6 Address for correspondence (if different from address given in section 1) Address

postcode

country

Signature

Date and place

\section{Please indicate your interests in Divisions etc on the right}

National Member Societies constitution article 4b) Albanian Physical Society Albania, Armenian Physical Society Armenia, Austrian Physical Society Austria, Belarusian Physical Society Belorussia, Belgian Physical Society Belgium, Union of Physicists in Bulgaria Bulgaria, Croatian Physical Society Croatia, Physical Section of the Union of Czech Mathematicians \& Physicists Czech Republic, Danish Physical Society Denmark, Estonian Physical Society Estonia, Finnish Physical Society Finland, French Physical Society France, German Physical Society Germany, Hellenic Physical Society Greece, Eötvös Lorand Physical Society Hungary, Icelandic Physical Society Iceland, Royal Irish Academy Ireland, Israel Physical Society Israel, Italian Physical Society Italy, Latvian Physical Society Latvia, Lithuanian Physical Society Lithuania, Society of Physicists of Macedonia Macedonia, Netherlands Physical Society Netherlands, Norwegian Physical Society Norway, Polish Physical Society Poland, Portuguese Physical Society Portugal, Romanian Physical Society Romania, National Committee of Russian Physicists Russia, Slovak Physical Society Slovakia, Society of Mathematicians, Physicists and Astronomers of Slovenia Slovenia, Spanish Royal Society of Physics Spain, Swedish Physical Society Sweden, Swiss Physical Society Switzerland, Turkish Physical Society Turkey, Ukrainian Physical Society Ukraine, The Institute of Physics United Kingdom

Collaborating Societies constitution article 4d) Europe European Optical Society, Société Française des Spécialistes d'Astronomie, Société Française d'Optique, Società Astronomica Italiana, Astronomische Gesellschaft, Deutsche Bunsen-Gesellschaft für Physikalische Chemie, Deutsche Gesellschaft für Angewandte Optik, International Society for Theoretical Chemical Physics, Nederlandse Astronomenclub, The Division for Applied Physics of the Royal Institution of Engineers, Sociedad Española de Optica, Société Suisse d'Optique et de Microscopie Electronique

World Wide American Physical Society, Australian Institute of Physics, Canadian Association of Physicists, Japan Society of Applied Physics, Physical Society of Japan

Which of the following Divisions, Sections and Groups do you wish to join? please tick

Divisions \& Sections

Astrophysics $\bigcirc$ Solar Physics

Atomic \& Molecular Physics

Atomic Spectroscopy (EGAS) Chemical Physics

Electronic \& Atomic Collisions, Molecular Physics

- Condensed Matter

L Liquids, O Low Temperature Physics

O Macromolecular Physics, $\bigcirc$ Magnetism

Semiconductors \& Insulators, Surfaces \& Interfaces

- High Energy \& Particle Physics

- Nuclear Physics

- Plasma Physics

Q Quantum Electronics \& Optics

- Statistical and Non-Linear Physics

Interdivisional Groups

- Accelerators

Applied Physics \& Physics in Industry

- Computational Physics

Physics for Develoment

- Physics Education

- Experimental Physics Control Systems

- History of Physics

europhysics news MARCH/APRIL 1999 